\title{
Potential Economic Impacts of Restoring Commercial Oyster Harvest Levels in Apalachicola Bay, Florida ${ }^{1}$
}

\author{
Robert Botta, Ed Camp, Christa Court, Caleb Stair, and Charles Adams²
}

\section{Introduction}

Florida's Apalachicola Bay (located in Franklin County) has been known for its oyster harvesting and processing industry for a long time. However, a sharp decline in oyster landings beginning in 2012 has threatened the industry and prompted the Secretary of Commerce to declare a fishery disaster in 2013 (NOAA 2013). The oyster harvest in Franklin County dropped from over 460,000 bushels in 2012 to under 10,000 bushels in 2018, a 98\% decline (Figure 1). Similar to other Gulf of Mexico areas (Peyre et al. 2014), there are increasing efforts to restore oyster reefs in Apalachicola Bay with the intention of restoring oyster populations and the ecosystem and economies they support. In fact, the Florida Fish and Wildlife Conservation Commission recently suspended wild harvest of oysters in Apalachicola Bay for five years to boost populations, improve ecosystem health, and restore sustainable levels of wild harvest. To make good decisions about ongoing and future restoration, it is important to understand how restored Apalachicola oyster fisheries could actually affect the local economy. The purpose of this document is to describe the potential economic impacts of successful oyster reef restoration in Apalachicola Bay. This information should help stakeholders, agencies, and governments by informing the decisions they must make about restoration, as well as their expectations for its effect on the economy. However, it is important to recognize that this document does not describe the steps necessary to complete oyster restoration projects, nor does it assess the likelihood of any particular oyster restoration project's success-it simply describes what the likely economic effects would be if the restoration succeeded to varying degrees.

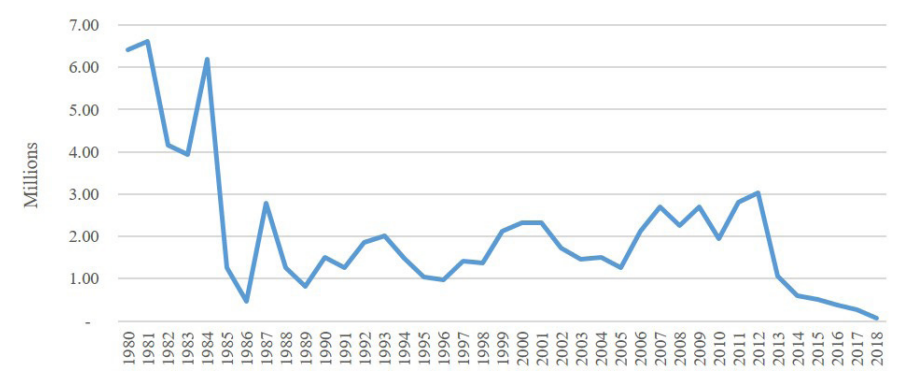

Figure 1. Apalachicola Bay historical oyster landings, in meat pounds (Florida FWC 2019).

\section{Restoring Apalachicola Bay's Oyster Population}

The Apalachicola Bay oyster fishery and its decline has been controversial (Camp et al. 2015) and is currently related to an ongoing Supreme Court case, making it important to describe some background about what scientists think they know and do not know. Declining oyster populations in Apalachicola Bay were probably caused by a combination

1. This document is FE1085, one of a series of the Food and Resource Economics Department, UF/IFAS Extension. Original publication date October 2020. Visit the EDIS website at https://edis.ifas.ufl.edu for the currently supported version of this publication.

2. Robert Botta, student, Program in Fisheries and Aquatic Sciences, School of Forest Resources and Conservation; Ed Camp, assistant professor, fisheries and aquaculture governance, Program in Fisheries and Aquatic Sciences, School of Forest Resources and Conservation; Christa Court, assistant scientist, Food and Resource Economics Department; Caleb Stair, lecturer, Food and Resource Economics Department; and Charles Adams, emeritus professor, Food and Resource Economics Department; UF/IFAS Extension, Gainesville, FL 32611.

The Institute of Food and Agricultural Sciences (IFAS) is an Equal Opportunity Institution authorized to provide research, educational information and other services

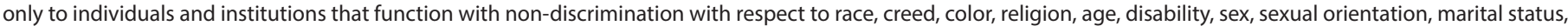

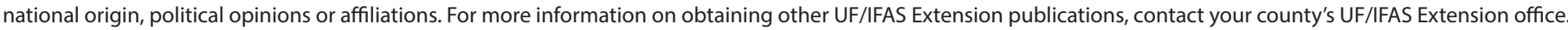
U.S. Department of Agriculture, UF/IFAS Extension Service, University of Florida, IFAS, Florida A \& M University Cooperative Extension Program, and Boards of County Commissioners Cooperating. Nick T. Place, dean for UF/IFAS Extension. 
of factors, but proving which was the most important or consequential has been challenging. Some of the potential factors linked to decline include 1) changing freshwater flow from the Apalachicola River, which affects the salinity in the Bay and might affect oyster survival (Wilber 1992); 2) unusually low survival, especially of young oysters, that might have been made worse by loss of oyster reef habitat (Pine et al. 2015); and 3) heavy fishing pressure and harvested adult oysters (Pine et al. 2015; Bendick et al. 2018), which would have contributed to reef habitat loss. While a lot of research has studied which of these or other factors was most responsible for the decline (Havens et al. 2013), there is not a broad agreement on this topic. What is clear is that the decline in oysters has not reversed and might be getting worse.

The worsening decline has led to several management changes. The Florida Fish and Wildlife Conservation Commission (FWC), which manages wild oyster harvest, has decreased daily commercial harvest limits and started weekend closures during the oyster season. Restoration actions have also begun. In 2013, the FWC was awarded about \$4 million to restore roughly 18 acres of oyster reefs. In the last year, Triumph Gulf Coast, Inc., funded a project led by Florida State University that proposes to further restore the Apalachicola Bay oyster reefs and overall ecosystem health (FSUMCL 2019). Finally, in late 2019, the FWC received a commitment from the National Fish and Wildlife Foundation (NFWF) to fund a larger oyster restoration project over the next 3-4 years. Ideally, these restoration initiatives and management changes will lead to a healthier Apalachicola Bay system that includes oyster reef habitat that could eventually support a sustainable and commercially viable oyster harvest and processing industry once again.

Restoring both economic and ecological benefits from oyster reefs might be possible but will require significant effort. Additionally there is a lot of uncertainty about how effective the restoration efforts might be. Uncertainties include:

- How successful oyster restoration will be in actually increasing the oyster population that would allow sustained commercial harvest. Just the restoration portion has a lot of uncertainty, especially related to what types of restoration materials will work best (e.g., old oyster shell, rock, or other materials), how to apply them (e.g., how tall should the restored oyster reefs be made), and what other management actions (like changing water management or oyster fishing regulations) are needed (Pine et al. 2015; Moore et al. 2018).
- Oyster population recovery will take time, which will delay the associated economic effects. However, scientists do not yet know how long the restoration is expected to take, as this will depend on the current spawning oyster population (which is not well known) as well as the effects of restoration described above. Together these might make current economic estimates unreliable.

- The type of wild harvest of oyster reefs (i.e., the removal of oyster shell through tonging) affects the future generations of oysters because the young oyster usually grows on living or freshly dead oyster shell. However, scientists do not yet know whether there is some minimum "threshold" of oyster reef shell that must be provided to sustain populations, and if there is, what it might be.

The result of these uncertainties is that there is no guarantee that the restorations completed, in progress, and planned will be able to successfully restore the commercial oyster fishery in Apalachicola Bay to what it once was. If some restoration is successful, we still do not know exactly what levels of fishing will be sustainable or for how long.

\section{Economic Impact of Restoring the Bay}

To understand what the economic effects of successful oyster restoration might be, we need to assume how oyster harvest would change following restoration and then use economic analysis tools to see how activity associated with wild oyster harvest would reverberate through the economy. Several of a range of potential annual oyster harvest levels were modeled for Franklin County under the assumption that oyster reef restoration in Apalachicola Bay was successful. Potential annual harvest levels were based on historical harvest levels and include: 100,000; 200,000; 300,000; and 400,000 bushels of oysters. (Harvests reported in meat pounds were converted to bushels using the Whole Weight Conversions table provided by the Florida Fish and Wildlife Conservation Commission. [Each bushel of oysters contains 6.5625 meat pounds.]) For reference, the landings from 2006-2018 (Figure 1) peaked at around 460,000 bushels in 2012, while current landings are around 4,500 bushels. This means that even the lowest levels of restoration (100,000 bushels/year) would represent a large improvement in landings. For each harvest scenario, historical prices associated with harvest levels within a range of $+/-50,000$ bushels relative to the desired production level as well as the most recently published price were used to identify the minimum, maximum, and average price of the harvests within that range. (All prices were converted to 2018 dollars [US BEA 2018].) 


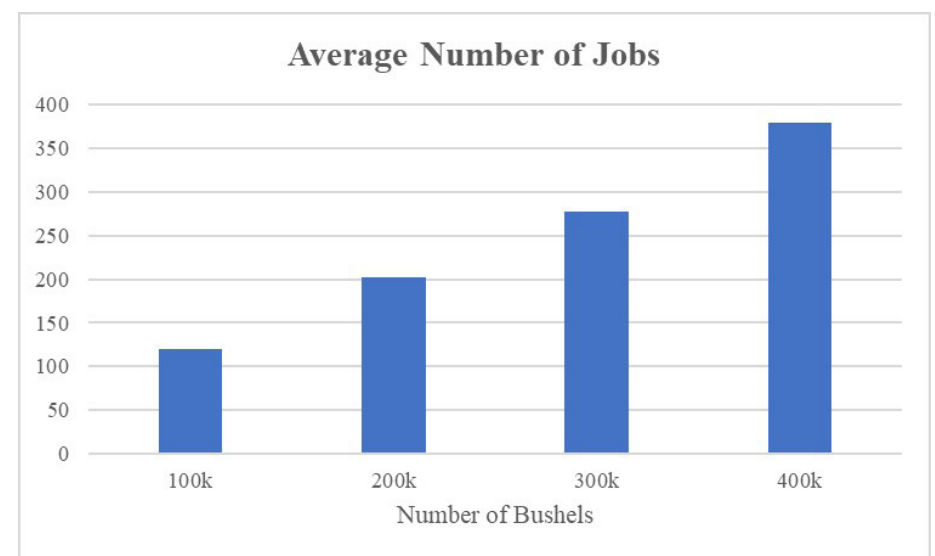

Figure 2. Average economic impacts of restoring oyster production based on hypothetical harvest thresholds-average number of jobs.

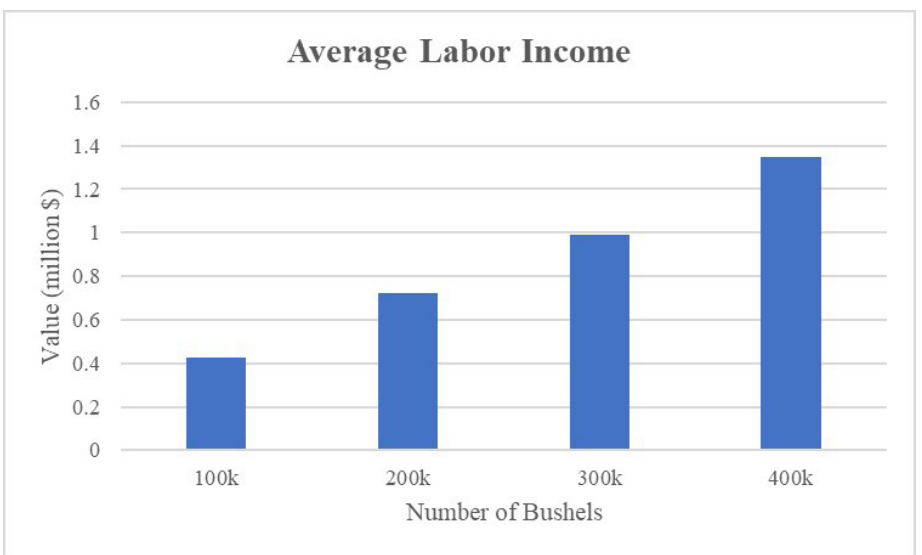

Figure 3. Average economic impacts of restoring oyster production based on hypothetical harvest thresholds-average labor income.

Understanding how a restored oyster fishery could result in broader regional economic effects (sometimes called multiplier effects) requires an economic impact analysis. Such an analysis is useful because it takes local, countyspecific information and calculates how a change (like an increase in oyster landings) would translate to additional economic activity generated through supply chain spending and the re-spending of household income. For example, increased oyster landings would mean more oysters sold, but also more ice, gas, and other oyster fishing supplies purchased, as well as changes in the personal spending made by oyster fishers and individuals employed in other supporting industries.

We analyzed the economic impacts with each hypothetical increase in commercial fishing activity (e.g., 100,000400,000 bushels/year) using the IMPLAN ${ }^{\odot}$ regional economic modeling system and the associated database that depicts the regional economic structure of Franklin County, Florida in 2017 (IMPLAN ${ }^{\odot}$ Group, LLC). This model and approach is one of the most common for assessing economic impacts and has been used in Florida for many

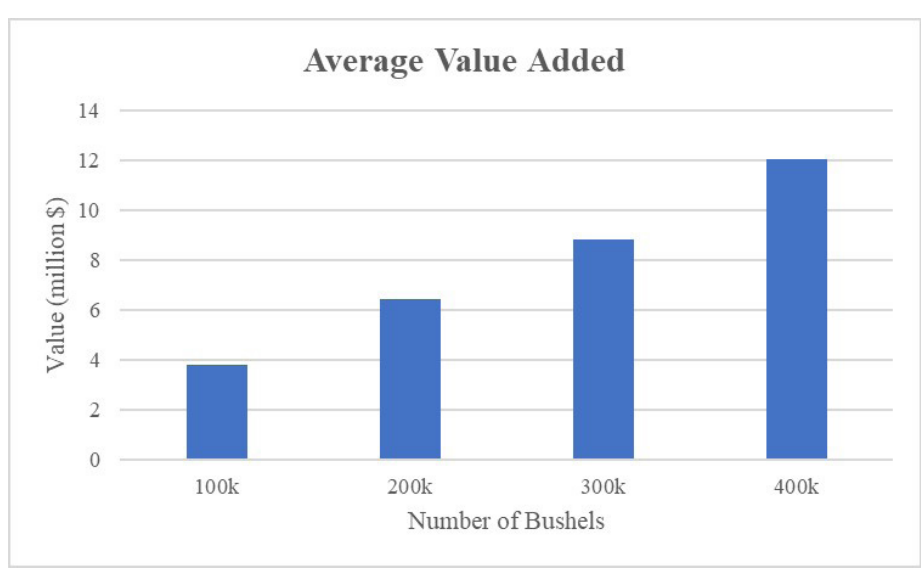

Figure 4. Average economic impacts of restoring oyster production based on hypothetical harvest thresholds-average value added.

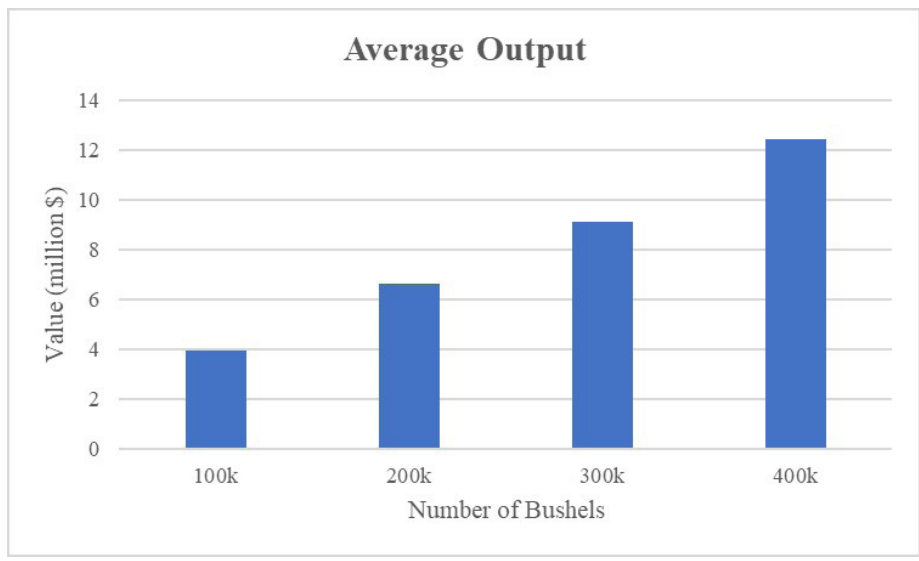

Figure 5. Average economic impacts of restoring oyster production based on hypothetical harvest thresholds-average output.

different industries. For these scenarios, the estimates of total economic impacts are comprised of three components:

- Direct effects: The increase in commercial fishing activity associated with each hypothetical harvest scenario, which represents the increased revenue to oyster fishers from increased harvest sales.

- Indirect effects: The increased activity associated with supplier industries within Franklin County that result from purchases of the commercial fishers as well as other activities throughout the supply chain (e.g., increased expenditures on items such as fuel and boat repairs).

- Induced effects: The increased expenditures by households of employees and business proprietors in directly and indirectly impacted businesses for personal consumption of housing, utilities, groceries, etc.

Each scenario used minimum, maximum, and average annual values to generate a range of potential impacts for the scenario in terms of employment, labor income, value added, and output. Table 1 includes the minimum and maximum impacts for each scenario. The average economic impacts for each scenario are seen in Figure 2. 
Table 1. Minimum and maximum economic impacts of restoring oyster production based on hypothetical harvest thresholds

\begin{tabular}{|c|c|c|c|c|c|c|c|c|}
\hline Bushels & \multicolumn{2}{|c|}{100,000} & \multicolumn{2}{|c|}{200,000} & \multicolumn{2}{|c|}{300,000} & \multicolumn{2}{|c|}{400,000} \\
\hline & Min. & Max. & Min. & Max. & Min. & Max. & Min. & Max. \\
\hline \# of jobs & 43 & 152 & 65 & 211 & 126 & 212 & 172 & 304 \\
\hline $\begin{array}{l}\text { Labor } \\
\text { income }\end{array}$ & $\$ 151,227$ & $\$ 540,792$ & $\$ 230,254$ & $\$ 749,250$ & $\$ 446,203$ & $\$ 755,165$ & $\$ 612,382$ & $\$ 1,079,499$ \\
\hline Value added & $\$ 1,353,163$ & $\$ 4,838,963$ & $\$ 2,060,293$ & $\$ 6,704,222$ & $\$ 3,992,586$ & $\$ 6,757,153$ & $\$ 5,479,541$ & $\$ 9,659,262$ \\
\hline Output & $\$ 1,392,205$ & $\$ 4,978,581$ & $\$ 2,119,739$ & $\$ 6,897,658$ & $\$ 4,107,784$ & $\$ 6,952,116$ & $\$ 5,637,642$ & $\$ 9,937,960$ \\
\hline
\end{tabular}

\section{Conclusions}

The Apalachicola Bay oyster fishery has faced droughts, hurricanes, intense fishing effort, and other challenges in the past, but the current circumstances present a new obstacle for resource managers to overcome. Global trends in climate and human populations suggest that associated stress to areas such as Apalachicola Bay are likely to continue (Camp et al. 2015). Therefore, harvest levels that can be achieved in the future depend on the use of available restoration funds to successfully rebuild harvestable oyster populations and to develop management practices capable of sustaining these populations.

What we found here highlights the range of potential economic impacts of different restoration scenarios. While there is substantial uncertainty regarding the effects and timing of restoration, there certainly will be positive economic impacts should the restoration result in renewed and sustained oyster fisheries. Restoring oyster fisheries to the levels described here could also lead to additional economic effects, likely positive, from an enhanced oyster fishery for industries such as seafood product preparation and packing, wholesale and retail seafood sales, and tourism. Additionally, the restoration of the oyster fishery would require such an increase in oyster populations that it would almost certainly increase the ecosystem services that oysters provide, like filtering water and providing habitat for fish and other animals.

Although there are substantial, positive economic impacts of a fully restored oyster fishery, these all depend on restoration effectively rebuilding oyster populations to the level that they can sustain that harvest. This analysis has not assessed whether the harvest scenarios modeled, which are based on historical ranges, are even temporarily achievable through restoration, much less sustainable in the long run. Therefore, it is critically important that this document be understood to only describe the economic impacts that are possible if that level of harvest were to be sustained. This study also does not include an assessment of the costs of restoration (which are likely to be substantial). A full cost/ benefit analysis, which would ideally include an assessment of realistic expectations of commercial harvest levels supported, is needed to assess the ultimate benefit of oyster restoration efforts in Apalachicola Bay.

\section{References}

Bendick, R., B. DeAngelis, and S. Blitch. 2018. "Oyster Restoration in the Gulf of Mexico." The Nature Conservancy.

Camp, E. V., W. E. Pine III, K. Havens, A. S. Kane, C. J. Walters, T. Irani, A. Lindsey, and J. G. Morris Jr. 2015. Collapse of a Historic Oyster Fishery: Diagnosing Causes and Identifying Paths toward Increased Resilience. Ecology and Society 20 (3): 45. http://dx.doi.org/10.5751/ ES-07821-200345.

Florida Fish and Wildlife Conservation Commission (FWC). 2019. Commercial Fisheries Landings Summaries. Retrieved October 21, 2019. https://public.myfwc.com/ FWRI/PFDM/ReportCreator.aspx

Florida State University Coastal \& Marine Laboratory. 2019. Apalachicola Bay System Initiative. Proposal application submitted to Triumph Gulf Coast, Inc. Trust Fund. https:// marinelab.fsu.edu/media/3323/69-fsucml_triumph_absi. pdf

Havens, K., M. Allen, E. Camp, T. Arani, A. Lindsey, J. G. Morris, A. Kane, D. Kimbro, S. Otwell, B. Pine, and C. Walters. 2013. Apalachicola Bay Oyster Situation Report. TP-200. Florida Sea Grant Program, Institute of Food and Agricultural Sciences, University of Florida. Gainesville, FL.

IMPLAN Group, LLC. IMPLAN economic impact analysis and social accounting software, and regional economic data for the State of Florida. Huntersville, NC, 2017, http://www. implan.com/.

Moore, J. L., B. J. Puckett, and S. J. Schreiber. 2018. "Restoration of Eastern Oyster Populations with Positive Density Dependence." Ecological applications 28 (4): 897-909. 
National Oceanic and Atmospheric Administration

(NOAA). 2013. Fishery Disaster Determinations.

NOAA Fisheries. https://www.fisheries.noaa.

gov/national/funding-and-financial-services/

fishery-disaster-determinations\#numbers-72---54

2019. Annual Commercial Landing Statistics Database.

Retrieved January 20, 2019. https://www.st.nmfs.

noaa.gov/commercial-fisheries/commercial-landings/

annual-landings/index

Peyre, M. L., J. Furlong, L. A. Brown, B. P. Piazza, and K.

Brown. 2014. "Oyster Reef Restoration in the Northern

Gulf of Mexico: Extent, Methods and Outcomes." Ocean \&

Coastal Management 89: 20-28.

Pine III, W. E., C. J. Walters, E. V. Camp, R. Bouchillon, R.

Ahrens, L. Sturmer, and M. E. Berrigan. 2015. "The Curious

Case of Eastern Oyster Crassostrea virginica Stock Status in

Apalachicola Bay, Florida." Ecology and Society 20 (3): 46.

http://dx.doi.org/10.5751/ES-07827-200346

US Bureau of Economic Analysis (BEA). 2018. Gross

Domestic Product Implicit Price Deflator, Washington, D.C.

Retrieved: August 27, 2018. https://apps.bea.gov/iTable/

index_nipa.cfm.

Wilber, D. H. 1992. "Associations between Freshwater In-

flows and Oyster Productivity in Apalachicola Bay, Florida."

Estuarine, Coastal and Shelf Science 35 (2): 179-190. 